Trinity University

Digital Commons @ Trinity

English Faculty Research

English Department

Summer 2018

\title{
Novel Commonplaces: Quotation, Epigraphs, and Literary Authority
}

Claudia Stokes

Trinity University, cstokes@trinity.edu

Follow this and additional works at: https://digitalcommons.trinity.edu/eng_faculty

Part of the English Language and Literature Commons

\section{Repository Citation}

Stokes, C. (2018). Novel commonplaces: Quotation, epigraphs, and literary authority. American Literary History, 30(2), 201-221. doi: 10.1093/alh/ajy005

This Article is brought to you for free and open access by the English Department at Digital Commons @ Trinity. It has been accepted for inclusion in English Faculty Research by an authorized administrator of Digital Commons @ Trinity. For more information, please contact jcostanz@trinity.edu. 


\title{
Novel Commonplaces: Quotation, Epigraphs, and Literary Authority
}

\author{
Claudia Stokes*
}

Until the middle of the nineteenth century, commonplacing was a habitual practice of middle-class US households, undertaken by children and adults alike to record notable quotations and to cultivate their literary taste. Though it declined in popularity with the rise of the scrapbook in the midcentury, commonplacing was for centuries a standard feature of both educational curricula and domestic literacy, with generations of students instructed in the intellectual and moral benefits of selecting and copying passages culled from reading. Commonplace books offer a wealth of vital information about US literary culture, for they not only illuminate eighteenthand nineteenth-century reading practices by allowing us to discern what US readers valued in various genres, but they also help to document what middle-class and well-to-do Americans were reading. In showing that many Americans were attentively reading and excerpting the works of such less remembered figures as Caroline Sheridan Norton, Charles A. Sprague, and Edward Young, these books may even be said to reveal an alternative canon of nineteenth-century national reading preferences. In addition, commonplace books also affirm the particular status of the quotation, which was so prized that readers dedicated much of their time to the selection and transcription of select passages. According to Barbara Benedict, these handpicked excerpts revealed both the reader's taste in as well as his or her eye for a well-chosen phrase or a keen observation, and as

\footnotetext{
*Claudia Stokes is Professor of English at Trinity University. She is the author of The Altar at Home: Sentimental Literature and Nineteenth-Century American Religion (2014) and Writers in Retrospect: The Rise of American Literary History, $1875-1910$ (2006). She is currently writing a book about unoriginality and familiarity in nineteenth-century US literature.
} 
evinced by the frequency with which commonplacers exchanged and commented on each other's selections, readers could readily expect to be judged for their choice of quotations (51).

Despite the significant evidentiary value of commonplace books, they have attracted little scholarly attention in part because, until the advent of digitized archives, the contents of these books remained largely untraceable, for compilers seldom identified the source of the passages they inscribed. Twentieth-century critical and scholarly tenets also contributed to their neglect: once critics widely accepted the New Critical regard for innovation as the distinguishing hallmark of literary achievement, commonplace books came to seem retrograde and even antithetical to literary change. Their diligent inscriptions of moralistic verse and sermons preserve literary tradition and ensure its uninterrupted continuity, thereby seemingly impeding the literary experimentation esteemed by modern critics. However, as I will argue, commonplacing and its primary constituent, the quotation, occupied a more complicated role in the rapidly changing literary world of the midcentury. Though commonplacing typically promoted literary preservation and traditionalism, it nonetheless helped to legitimate disputed new genres and atypical authors who would otherwise struggle to find their way into print. The practice of quoting older literary material, which the commonplace book promoted and imbued with prestige, had long aided ambitious upstarts eager for a public audience, but by the midcentury, it became especially useful to women writers and writers of color, who cannily took advantage of the commonplacing tradition, using quotations to affirm their fidelity to literary convention and to demonstrate their qualifications to enter the literary public sphere. The invocation of older literary material thus enabled the rise of new forms and new authors, who used these quotations to demonstrate their knowledge of and commitment to the literary past, and, in so doing, affirmed their fitness for a public audience. In this way, the rise of the new was contingent on its explicit homage to the old.

\section{The History of Commonplacing}

Commonplacing was originally conceived as a memory aid designed to help readers retain noteworthy passages. From the very outset it functioned as a bulwark against loss, enabling the preservation of texts against the inevitable erosion of memory. ${ }^{1}$ The term "commonplace" was originally coined by Aristotle, who, in promoting the study of wise sayings, dubbed these apothegms topoi koinos, literally "common places," a term echoed in Cicero's phrase loci communes, "common places," which, if studied, could occupy 
important central space in the mind. As Margreta de Grazia observes, the quotation mark first developed specifically to mark a noteworthy passage regarded as a commonplace, collectively owned and universally agreed upon (287-89). Although the term commonplace suggests community possession of this wisdom, discourse surrounding this form produced an alternative understanding of the commonplace book as the exclusive property of economic privilege. Commonplacing was initially the province of the literate, leisured elite equipped with the training and discernment necessary to select choice passages and have a stake in literary conservation. As a result, commonplace books were often described as treasuries or storehouses filled with riches, a metaphor that contributed to the perception of extracted wisdom as a precious, rare commodity available to the elite and thus in need of protection against loss. ${ }^{2}$

This association with privileged wealth made commonplacing attractive to ambitious readers intent on social mobility. Even in antiquity, young men hoping to enter public life were encouraged to collect commonplaces - select quotations and pithy sayings — on the grounds that these passages might supply useful content for oratory and debate. In this case, the skillful integration of commonplaces into oratory corroborated their fidelity to tradition and their fitness for an audience, thereby qualifying them to enter into public discourse and to achieve status. In the Middle Ages, Quintilian similarly recommended memorizing commonplaces to improve verbal fluency; he describes commonplaces as sedes, as "seats" or dependable resting places that could both provide precedent and affirm credibility in oral debate (Havens 15; Miller 22). By the sixteenth century, humanist education encouraged the collection and recitation of select sententious quotations, which facilitated upward mobility for non-elites by confirming their respectability as well as their submission to established structures of intellectual and social authority (Crane 6, 13; Morson 259-60; Sherman 44). The collection and public recitation of commonplaces, Mary Thomas Crane argues, were simultaneously "empowering and controlling, enabling and limiting": these quotations restricted what these young men were allowed to say by constituting an approved script for public discourse, but in so doing they also permitted access to otherwise unavailable social spheres (8). The well-chosen quotation thus qualified students to cross social and economic borders and enter into territory restricted to the privileged.

Commonplacing traditionally served as a means of selfimprovement, and following the American Revolution, the practice became a fixture of a liberal education in the US. Advocates urged readers to create a personal archive of worthy passages that might edify, refine, or motivate: compilations of well-chosen extracts, it 
was believed, could serve as a lifelong fount of inspiration and a compelling inducement to self-betterment. For this reason, prominent rhetoricians widely recommended the transcription, study, and imitation of exemplary passages, as with Hugh Blair's Lectures on Rhetoric and Belles Lettres (1783), which remained influential in the US well into the nineteenth century. Blair repeatedly insisted on the educational merits of rewriting and studying choice quotations, recommending that students attempt to rewrite excerpts from memory so that they might see "where the defects of [their] style lie" and "lead [them] to the proper attentions for rectifying them" (204). Nineteenth-century rhetorician Henry N. Day similarly encouraged the careful study of worthy quotations, for it "is hardly practicable for the human mind to obtain a clear and familiar knowledge of any art without illustrations and exemplifications" (15). For generations of US students, the study of letters entailed the diligent transcription of select passages, a practice that did not cease once they left school, for they were strongly encouraged to continue this habit in their adult lives through commonplacing. ${ }^{3}$ For much of US history, literacy was characterized by adept recitation and apt quotation.

As a practice, commonplacing simultaneously preserved literary tradition and enabled social mobility, but by the early nineteenth century this negotiation became more complex and more tenuous. Though commonplacing usually safeguarded traditionalism, advocates suddenly began to promote it to middle-class white women. Louisa Tuthill, for instance, urged readers of her domestic manual The Young Lady's Home (1839) to keep commonplace books so that they might develop their intellects and become more engaged readers, advice that Sarah Hale had similarly issued the year before in Godey's Lady's Book (Miller 28). This campaign constituted an effort to remedy several worrisome changes in female literary activity. Commonplacing, Tamara Plakins Thornton has argued, emerged as a corrective to the increasing public visibility of women writers (59$60)$. Conservative social critics and educational reformers believed that assiduous notetaking could prevent women from improperly seeking to enter the literary public sphere: commonplacing, proponents hoped, would occupy the entirety of a woman's literary attention and thereby leave little room for creative endeavors designed for a public audience. In this way, commonplacing promised to transform the female literary aspirant into a private literary copyist, who spends her time merely transcribing the writing of others instead of producing her own original compositions. While commonplacing had for generations helped young men enter public life, by the early nineteenth century, this practice worked to prevent women from achieving similar renown and mobility. In this particular setting, commonplacing continued to preserve literary traditionalism 
by preventing changes to authorial demographics, protecting literary separate spheres, and quelling potential social change.

At the same time, commonplacing also emerged as a solution to anxieties about female reading. The rise of the novel in the eighteenth century famously sparked widespread concern about the impact of these narratives on young women, whose vulnerability to deleterious influence was so often the subject of early Englishlanguage novels such as Daniel Defoe's Roxana (1724) and Charlotte Lennox's The Female Quixote (1752). Until the ascent of literary sentimentalism in the 1850s, novel-reading in the US was widely regarded as a harmful influence that made young women vulnerable to seduction, madness, and even suicide (Nord 118). Critics believed that novels encouraged uncritical interpretive habits that could prove harmful or even fatal to young women, and they urged women not only to shun novels altogether but also to keep a commonplace book in which they recorded excerpts from more respectable reading material, such as verse or moralistic prose. Whereas the novel was understood to produce credulous and voracious reading habits, the commonplace book was associated instead with attentiveness and thoughtfulness, by which young women might learn the discernment necessary to resist the dangers of fiction as well as temptations more generally. Tuthill, for instance, counseled her readers to "abjure novels" and use a "note-book" to record noteworthy passages $(40,46)$. Women commonplacers of the nineteenth century sometimes commented directly on this injunction, as with the inscription from a young woman's book from 1815-1816, in which she wrote,

Perhaps half the evils of life arise from frivolous reading, and still it is pursued with an ardour almost irrepressible by the unthinking youth of this generation. Novels and romances tend to weaken the understanding, fill the brain with wonderfull chimeras, blunt the sensibilities of the soul and awaken the vanity, together with the weak passions of the mind. (Read 22-23)

The association of commonplacing with female resolve is observable even from the very beginning of the English-language novel: as Leah Price has observed, two of the most famous heroines of early novels, Samuel Richardson's Pamela (1740) and Clarissa (1748), each keep commonplace books in which they copy sage passages taken from their reading (13-14). Though both women are vulnerable to danger, they respectively resist their would-be seducers, their immunity to harmful influence implicitly associated with the discernment cultivated by commonplacing. Commonplacing, these novels suggest, could save a woman's life. 
Though commonplacing was promoted as a solution to the dangers posed by novels, this practice was nonetheless enlisted to buttress this disputed new form. This assertion goes against the grain of conventional scholarly treatments of commonplacing, which have typically overlooked fiction to consider instead the impact of this practice on poetry, as verse accounted for the majority of commonplace book inscriptions. ${ }^{4}$ David Allan has also argued that the novel and the commonplace book were essentially irreconcilable and asserted that the rise of the novel contributed to the decline of commonplacing (256). Yet this claim oversimplifies the textured relationship between the two and overlooks how commonplacing exerted visible influence on the novel, which similarly began to incorporate extracted passages in keeping with the customs of this readerly practice. Following the foundational work of Mikhail Bakhtin, scholars have for decades recognized the heteroglossic intertextuality of novels, beginning with the epistolarity of early English-language novels, and so it is nothing new to contend that novels assimilated other literary genres and forms. However, by the turn of the nineteenth century, novels began to imitate the commonplace book by including abundant quotations drawn from the same canon of sources that filled commonplace books of the period: verses by such poets as Anna Lætitia Barbauld, Robert Burns, Lord Byron, and James Thomson; scriptural quotations; and writings by novelists Sir Walter Scott and Madame de Staël all began to pervade English-language novels. ${ }^{5}$ These quotations typically appeared in the form of the epigraph, the quotation used to mark chapter breaks and forecast plot events. Though epigraphs may seem merely ornamental, they nonetheless originated in the arduous work of commonplacing, as novelists had to peruse countless texts to find passages that suggestively mirrored the plots of their chapters. In fact, Scott complained about the painstaking work that underlay epigraphs and resorted to composing his own verses to avoid commonplacing, according to Willis Regier (107). Epigraphs tacitly worked to minimize the ostensible novelty of novels, for they confirmed both the sterling literary antecedents of each chapter as well as the novel's visible reliance on esteemed literary sources. In addition, epigraphs also enlisted the credentialing authority of commonplacing, for they implicitly presented novelists themselves as careful, perspicacious readers both familiar with the established literary canon and committed to preserving that traditional literary practice in their own works. As a result, epigraphs helped to address public concerns about novel-reading by corroborating novelists' own readerly discernment and solid grounding in literary convention and practice. Epigraphs and quotations, that is, allowed novelists to depict their 
works as continuations of-rather than dangerous threats toliterary tradition.

\section{Literary Quotation in the US}

The literary advantages of commonplacing were by no means limited to the legitimation of the novel form. Rather, commonplacing proved a particular boon to US writers on the literary periphery eager to acquire a public audience. In accord with the traditional uses of commonplacing as a conduit of social mobility, quotations and epigraphs acquired special favor among women and writers of color, who eagerly embraced the excerpt as a means of affirming their respectability and conventionality. Though conservative social critics recommended commonplacing to constrain female literary ambition, this practice ended up launching countless US writers from the literary margins, who used quotations like a chaperone verifying their familiarity and compliance with established literary tradition. By the midcentury, the epigraphic quotation became so popular that it essentially became the literary calling card of women and writers of color.

Gérard Genette has shown that interleaved quotations first appeared in 1678 with François de La Rochefoucauld's Maxims, but the epigraph in particular was first popularized in late eighteenthcentury Britain, and it eventually migrated to the US by the second decade of the nineteenth century (145). It began with Ann Radcliffe's immensely popular gothic novel The Mysteries of Udolpho (1794), which included epigraphic quotations in addition to dozens of interpolated lyric verses. According to Terry Castle, excerpted passages by such eminent figures as John Milton and William Shakespeare imbued "her narrative with a kind of supplemental 'poetic' authority" and allayed anxieties about the novel form by firmly grounding The Mysteries of Udolpho within an august lyric tradition (xiii). Modern critics have likened Radcliffe's interpolated lyrics to "textual speed-bumps" or "massy doors" that obstruct the unfolding of the plot, but these epigraphs nevertheless attested to Radcliffe's taste and literary knowledge (Price 96). Radcliffe's contemporaneous readers did not share modern critics' dislike because they perceived the quotation as an index of sensibility and refinement. As evidenced by the repeated presence of Radcliffe's verse in nineteenth-century US women's commonplace books, female readers seem to have discerned a strong affinity between her novels and the act of commonplacing, and they sought to preserve passages that more recent critics have deemed superfluous. ${ }^{6}$

[Commonplacing] ended up launching countless US writers from the literary margins.... By the midcentury, the epigraphic quotation became so popular that it essentially became the literary calling card of women and writers of color. 
Bolstered by the popularity of The Mysteries of Udolpho, the epigraph began to appear first in such gothic novels as Matthew Lewis's The Monk (1796) and Charles Maturin's Melmoth the Wanderer (1820), as Regier observes (107). Deidre Lynch and Ingrid Horrocks explain that the epigraph was particularly suited to the gothic novel because it made visible the continuing, even haunting influence of the past into the present, the quoted words of past writers and texts seeming to echo and even to foreshadow the events depicted in later works (Lynch 40; Horrocks 516-17). In keeping with the commonplace tradition, the epigraph thus demonstrated the continuity between the literary past and the present, as the former reaches into and shapes the latter. For this reason, the epigraph later became characteristic of the historical romance, as with Scott's immensely popular novels and then with his most famous US imitator, James Fenimore Cooper. As the epigraph eventually made its way to the US, its reception conveys competing attitudes toward the influence of the literary past, the European literary past in particular. US writers who openly acknowledged their reliance on European sources were more inclined to employ epigraphs, such as Washington Irving and Cooper. At the same time, epigraphs also ran afoul of the longstanding US effort to produce home-grown national literature unmarked by European precedent: not only were epigraphs first popularized by British novelists of considerable influence, but they also directly allowed US writers to refer to and even incorporate the words of the European literary past, and in so doing compromise the pursuit of US literary independence.

Within this literary climate, the midcentury writers who used the epigraph most frequently were women and writers of color, among them William Wells Brown, Lydia Maria Child, Hannah Crafts, Maria Susanna Cummins, Frederick Douglass, Fanny Fern, Catharine Maria Sedgwick, E.D.E.N. Southworth, and Susan Warner. ${ }^{7}$ The one striking exception is Harriet Beecher Stowe, who did not use epigraphs, perhaps because, as a member of the illustrious Beecher family, she did need to provide evidence attesting to her credentials for public discourse. By contrast, white male prose writers of the midcentury — such as Nathaniel Hawthorne, Herman Melville, Donald Grant Mitchell, and William Gilmore Simmsseldom used epigraphs. Edgar Allan Poe included epigraphs in such stories as "The Man of the Crowd" (1840) and "The Murders in the Rue Morgue" (1841), but, because he was famously sensitive to any indication of inappropriate literary reliance, these quotations worked primarily to signal his participation in the gothic mode that first popularized the epigraph. ${ }^{8}$ For women and writers of color, however, the very qualities that made the epigraph ill suited to the American pursuit of cultural and literary independence rendered it apposite for 
their literary needs. As a form, the epigraph openly acknowledges literary precedent, influence, and even dependence, which were necessary attributes for midcentury women and writers of color entering the public sphere of print. The quotation consequently became a potent resource that allowed them to affirm their taste, to acknowledge literary convention, and to defer modestly to established literary precedent. Epigraphs thus tacitly positioned these writers in a long tradition of commonplacing aspirants, who carefully gathered and wielded quotations to advance their social mobility and public standing.

The significant social and literary advantages of quotation, especially for ambitious literary women, lie at the center of Sedgwick's Clarence (1830), which dramatizes the circumstances that make quotation beneficial for aspirants seeking social status and literary authority. A conventional novel of manners about a US heiress, Gertrude Clarence, as she attempts to navigate New York society, Clarence has received scant treatment from critics ever since it was published, despite Sedgwick's recovery three decades ago by such scholars as Mary Kelley. ${ }^{9}$ Perhaps because this novel about social life among the affluent neither took up pressing social issues nor narrated US history, as her prior novels had, it has gone largely unrecollected; in contrast with Hope Leslie (1827), Clarence appears inconsequential. Yet, seemingly engineered to avert such a perception, Clarence is laden with learned quotations that attest to its solid grounding in literary tradition as well as the author's own dogged commonplacing in gathering all these passages together. As was typical of women's novels of the time, Clarence includes epigraphs at the beginnings of each chapter, excerpting the words of such commonly quoted writers as Burns, Byron, John Dryden, and Shakespeare.

In addition, the novel is explicitly preoccupied with the quotation as an authoritative gesture, as numerous characters openly use quotations to assert their status, with several excerpts appearing on nearly every page. For instance, in a courtroom scene in which Gertrude's father tries to prove himself the rightful heir to a fortune, a lawyer repeatedly quotes Shakespeare to anchor his arguments in lofty precedents, demonstrating that the original oratorical aims of commonplacing still obtained. In another scene, the villainous Pedrillo attempts to consolidate his authority over Mr. Layton, who owes him immense sums of money, by quoting Philippe Quinault in French. By declining to translate this quotation, Pedrillo conveys that he controls both the conversation and Layton's conduct, for Pedrillo will blackmail Layton into allowing him to marry his daughter, Emilie (Sedgwick 185). Later, Gertrude's suitor Gerald Roscoe exhibits his intellect by quoting a Latin adage, declaring by 
way of explanation, "'I am a learner, and you must allow me to use my golden opportunity. "The gods send opportunities-the wise man profits by them"...' he quoted the Latin saying in its original" (304). By verifying his self-identification as a "learner," Roscoe affirms his intellectual credentials, his fidelity to the past, and his appropriateness as a potential husband.

Furthermore, the novel repeatedly refers to the various channels by which quotations circulated, as with Sedgwick's acknowledgment that education typically entails "the most careful inculcation of wise precepts," a statement that invokes the centrality of commonplaces in educational curricula, which mandated the study, transcription, and memorization of such passages (136). In another scene, Mr. Clarence, upon seeing Emilie Layton, spontaneously quotes Chaucer, and explains that such quotation is a common oratorical practice: "Pardon me," he says, "I do not often quote, even prose" (142). Later in the novel, Sedgwick mocks a minor female character for her tendency to repeat ad infinitum the "sententious sayings" of her husband, treating him with the reverence with which one might regard a commonplace book (157).

These quotations begin to appear with such frequency, however, only after the heroine's father inherits an immense sum of money and enters into society, a chronology that confirms the link between the quotation and elite status. The most avid quoter in the novel is Mrs. Layton, whose social standing teeters on the brink of financial ruin thanks to her husband's gambling debts, and who, throughout the novel, offers pithy sayings and apothegms, often in French, to prove that she belongs among the upper ranks. In a letter to Gertrude, she quotes Madame de Staël, whose novel Corinne (1807) was a favorite among US women commonplacers: "Who is it that says (too truly!) that 'la puissance d'aimer est trop grande, elle l'est trop dans les ames ardentes!'” (190). ${ }^{10}$ After Gertrude lends her money to defray her debts, Mrs. Layton responds with a flurry of quotations, sardonically comparing her morose adolescent daughter Emilie to John Milton's "Il Penseroso" and quoting several lines from William Mason's "On the Death of a Lady." She here restores her equanimity with a conspicuous display of her knowledge: though she lacks financial capital, she demonstrates her possession of abundant intellectual capital, made possible by her evident compliance with the educational practices of commonplacing and her ready access to an infinite supply of select quotations.

Though the novel mocks Mrs. Layton's tendency to quote, Sedgwick herself repeatedly integrates quotations into the novel's third-person narrative voice, often even citing these texts' authors. For instance, Sedgwick cites Edward Gibbon in describing Gertrude's relationship with her father: "In this education of 
circumstances, there was one which had a paramount influence on the character of Gertrude Clarence-her intercourse with her father. Gibbon has said, that the affection subsisting between a brother and sister is the only Platonic love" (138). Elsewhere, she includes a line from Shakespeare's As You Like It (1623) in describing a dinner party: Gertrude "was in the parlor with Miss Layton, and awaiting her guests, when Judge Upton, who, true as a lover to his mistress, never broke 'the thousandth part of a minute in the affair' of a dinner, arrived" (156). Set against the backdrop of Mrs. Layton's own enthusiasm for quotation, these passages suggest that Sedgwick herself was similarly using extracts to assert her own respectability and elite standing. Sedgwick used epigraphs in Redwood (1824) and Hope Leslie, but her entrance into the less serious form of the novel of manners seems to have increased the need for quotation in order to affirm her respectability. In accord with the conventional uses of quotation to afford entrance into elite society, Sedgwick weighted the novel with abundant evidence of her own learning and faithful devotion to the literary past, which implicitly presented her as a trustworthy, deserving inductee in the literary public sphere.

Sedgwick's ambitions, however, were not restricted merely to deferential quotation. She also experimented with an epigraphic style that produced trenchant sentences suited to commonplacing. In so doing, Sedgwick presents herself as a keen wit deserving of quotation by others. Examples of this aphoristic style pervade the novel: for example, in describing Gertrude's vacation travel, Sedgwick writes, "Nothing is more characteristic of our country than the business-like way in which pleasure is pursued" (216). Elsewhere, she wrote, "duty cannot control or guide our subtle thoughts" (293). Such incisive passages are designed to distill complex belief systems into memorable, portable phrasings, and they bear witness to Sedgwick's own efforts to court quotation, whether in the private commonplacing of individual readers or in the epigraphic inscription of her fellow writers. Though it does not seem that these pithy statements were ever used in this way, Sedgwick nonetheless attempted to write in a mode that invited commonplacing and perhaps earned her membership in elite literary circles or even yielded literary immortality.

In sharp contrast with Sedgwick's reverential use of quotation, Fern acquired a different kind of standing as a result of her highly irregular use of epigraphs. By the time Fern became popular in the 1850 s, the most avid users of epigraphs were sentimental women novelists, like Cummins and Warner, who excerpted verses by renowned poets, like Shakespeare or William Wordsworth, to provide a commendable lyric precedent for their narratives about orphan girls struggling to achieve self-mastery. The plots of sentimental novels dutifully followed the contents of these epigraphs, just as 
their characters similarly learned to obey benevolent authority. Fern, however, played against this sentimental convention by explicitly rejecting both the views expressed in epigraphs as well as mainstream gender norms. Her columns often began with an unattributed epigraph offering some moralism about marriage or domesticity, but instead of using that excerpt to legitimate precedent for her writing, she instead often criticized those authoritative texts. For instance, her column "A Whisper to Romantic Young Ladies," published in the True Flag in June 1852, began with an epigraph that idealized poverty: "A crust of bread, a pitcher of wine, a thatched roof, and love, - there's happiness for you" (Fern, Ruth Hall 229). This epigraph leads the reader to expect Fern similarly to portray the capacity of love to temper poverty; she instead scathingly criticizes this view and exposes the inevitable hardships that women suffer in such circumstances, including constant pregnancies, hungry children, and backbreaking housework. In another column, "Sunshine and Young Mothers," published in the Olive Branch in July 1853, Fern began with an epigraph that asserted that it is "folly" for "girls to expect to be happy without marriage. Every woman was made for a mother. . . . If you wish to look at melancholy and indigestion, look at an old maid. If you would take a peep at sunshine, look at the face of a young mother"' (Ruth Hall 231). Fern's column begins by expressly repudiating the opinions in the epigraph, exclaiming, "Now I won't stand that!" and proceeds to give a counter-portrait of marriage in which the wife is more like a subservient drudge than a cheery homemaker, constantly waiting on her unappreciative husband and children (231). These epigraphs suggest that, against the grain of convention, Fern commonplaced quotations she deemed unworthy of preservation and used her columns precisely to undermine the cultural influence of such dicta.

The impact of Fanny Fern's prose derived in part from her persistent mockery of epigraphs. Though they traditionally conferred authority onto writers, Fern seized authority more aggressively by exposing the falsehoods and dangers that quotation conceals. In sharp contrast with established practice, Fern derived authority from critique, not deference, and she similarly urged her female readers to treat mainstream opinion skeptically, as when she begins the opening line of "A Whisper to Romantic Young Ladies": "Girls! that's a humbug!" (Ruth Hall 229). This irreverence is precisely what the quotation had been designed to dispel, with its assertions of pious reverence for established practice. Indeed, Fern became immensely popular for her willingness to challenge and even to mock cultural precedent and literary convention. 


\section{Quotation in the African American Literary Tradition}

Fern could exploit the epigraph in part because she wrote under a pseudonym and was thus invulnerable to personal censure, but African American writers similarly intent on social critique had to tread more carefully. Douglass was well acquainted with the conventional supplementary apparatus required for him to enter print, as evidenced by the letters by William Lloyd Garrison and Wendell Phillips that prefaced his 1845 Narrative of the Life of Frederick Douglass and vouched for his character and honesty. In The Heroic Slave (1853), his novella about the 1841 mutiny of the slave ship Creole, Douglass instead incorporated epigraphs, which similarly enlisted the words of reputable writers to verify both his literacy and piety. In addition, his epigraphs also provided lyric precedents for antislavery activism, such as his quotation from Thomas Moore's 1848 poem "Where Is the Slave": "Oh, where's the slave so lowly / Condemn'd to chains unholy, / Who could he burst / His bonds at first / Would pine beneath them slowly?" (Douglass 41). Douglass followed this passage with an excerpt from Byron's Childe Harold's Pilgrimage (1812-1818) that antislavery activists repeated widely: "Know ye not / Who would be free, themselves must strike the blow" (41). However, as Robert S. Levine, John Stauffer, and John R. McKivigan observe, Douglass made some editorial changes to Byron's language, which originally read "Hereditary bondsmen! know ye not / Who would be free, themselves must strike the blow!" (Levine et al. xviii). Douglass italicized the word "themselves" to suggest that slaves need not passively wait for emancipation and may instead justifiably incite rebellion. As controversial as this claim was for sparking worry in readers wary of slave insurrection, Douglass astutely used an epigraph to make this assertion for him, employing Byron's words to substantiate this view.

Quotation was particularly important to nineteenth-century African American writers for several reasons. Scholars have cited a long history of quotation in African American culture, enabled primarily by the significance of oral communication among illiterate slaves (Logan 15). Shirley Logan notes that former slaves often learned to read by memorizing and reciting lengthy passages in newspapers they heard read aloud (25). In keeping with the history of commonplacing, early African American oratory often entailed reciting memorized passages, like the three-hour speech that poet Lucy Terry Prince delivered at Williams College, in which she quoted liberally from scripture to advocate for her son's admission (Logan 1). Also in accord with this history, African American reformers actively promoted imitation as a means of uplift and social mobility. Just as ambitious young men of the early modern period 
memorized apothegms to imitate their social betters and attest to their respectability, so did numerous advocates like Douglass and Maria W. Stewart urge African Americans to emulate normative white conduct in an effort to achieve upward mobility (Wilson 89). This recommendation uneasily dovetailed with widespread racist stereotypes that regarded African Americans as natural mimics, notably Louis Agassiz's 1850 assertion to this effect (Wilson 97). However, activists and reformers attempted to leverage this stereotype and use it to African Americans' advantage; as Douglass asserted, "I believe in imitation. I think the disposition to imitate what is a little in advance of what we before knew is one of the most civilizing qualities of the human mind, and I am going to imitate all the good I can, and leave unimitated all the bad I find in the world" (qtd. in Wilson 100). Imitation need not reveal inferiority, Douglass avers, but may instead enable improvement.

Though imitation and quotation seemed poised to give African American writers new social and economic opportunities, popular rhetorics of the era used terms that quashed this ambition. Educators endorsed transcription, imitation, and recitation as essential to the development of verbal ability, but they also warned against an excess of imitation and did so in distinctively racialized language, likening it to slavery. Blair writes, "Slavish imitation depresses genius, or rather betrays the want of it" (371). Edward Young, whose poem Night Thoughts (1742-1745) frequently appeared in commonplace books, similarly characterized imitation as "servile," as did George Campbell in his The Philosophy of Rhetoric (1776) (Young 66; Campbell vii). Later nineteenth-century rhetoricians, like Henry N. Day, did too (16). For these theorists, extreme imitativeness indicated a lack of independent thought that could only undermine the speaker's ambition. Adroit imitation may signal ability and generate opportunities, but excessive imitation exposes a lack of skill and verges on outright fraud. African Americans were encouraged to quote and imitate in support of uplift, but rhetoricians characterized this tendency as the distinguishing mark of the former slave, who lacks the training to know how to use quotation properly and who, in so doing, exposes himself or herself as a parvenu. In this way, imitation functioned both as a marker of enslavement and as a means to escape it.

Brown's Clotel (1853) is doubtless the most famous example of nineteenth-century African American citational excess, for it included innumerable excerpts of newspaper articles, speeches, and poems as well as over a hundred plagiarized passages, which Geoffrey Sanborn has traced to such writers as Lydia Maria Child, Horace Greeley, and Harriet Martineau (14). ${ }^{11}$ Clotel, however, is less like a novel, a form distinguished by its teleological narrative 
horizon, than a topical commonplace book, brimming with textual excerpts on a particular subject, much like the many Civil War scrapbooks assembled in the 1860s. The influence of the commonplacing tradition is perhaps even more vividly evident in Hannah Crafts's The Bondwoman's Narrative (ca. 1858), a first-person gothic narrative about a slave, Hannah, and her efforts to save her biracial mistress, Mrs. Vincent, from the predations of the cruel Mr. Trappe. The Bondwoman's Narrative comports with established novelistic convention by using epigraphs, most of which are biblical and therefore confirm Crafts's piety and knowledge of scripture. Like Brown, Crafts also includes numerous lengthy passages copied from other writers and builds her novel on these interpolated excerpts, constructing a narrative that accommodates and enlarges on passages taken from Charlotte Brontë's Jane Eyre (1847), Charles Dickens's Bleak House (1853), and Scott's Rob Roy (1817). In this respect The Bondwoman's Narrative yields an important counterpoint to Allan's assertion that commonplacing was incompatible with the dense plotting of novels, which, he argues, rendered excerpting difficult (263). Crafts, however, seems to have had no trouble extracting passages from novels and inscribing them for her own literary use, following the commonplace tradition.

The Bondwoman's Narrative also evidences traces of the widespread educational uses of commonplacing. Though it was highly unlikely that, as a former slave, Crafts had been formally required to copy and study passages from exemplary writers, she appears to undertake such assignments in The Bondwoman's Narrative. For instance, Crafts not only copied numerous excerpts from Bleak House, but she also directly imitated it: the opening of the narrative, Daniel Hack notes, is a near word-for-word revision of Dickens's opening (34-35). ${ }^{12}$ And Hollis Robbins observes that the introduction of the narrator, Hannah, markedly resembles that of Esther Summerson in that Dickens novel (75). In the same vein, Crafts both includes passages copied from Jane Eyre and writes scenes directly patterned after it, as when Hannah eavesdrops on a private conversation while reading (Keyser 93). Unfortunately, according to the assertions of rhetoricians like Blair, these studiously imitative passages indirectly identify Crafts as a former slave who overcompensates for her lack of formal education by relying too much on the words of others: her imitation is slavish rather than sophisticated, and it presents her as an illicit plagiarist rather than a respectable contributor to public discourse.

At the same time, the contents of Crafts's narrative also dramatize the special status of quotation for the former slave. As Lynch proposes, epigraphs flourished in the gothic aesthetic because they allowed the words of the past to reverberate in the literary present 
and thus simulate the hauntings that were often central to gothic literature (40). In keeping with this convention, Crafts's narrative includes several episodes that invoke the supernatural, like the putatively haunted cabin where Hannah and her mistress take refuge. However, the quotation operates as a special source of terror in Crafts's narrative because, in the hands of the villainous Mr. Trappe, it helps to substantiate claims of racial heritage and slave ownership: the quotation allows the racial and legal past to upend the fragile present lives of former slaves. Mr. Trappe acquires influence specifically through his mastery of documentary records, "making his home among the books and papers" in the Lindendale library where he immerses himself in the textual residue of the past (Crafts 35). These researches result in the discovery that Mrs. Vincent is a biracial slave, and he uses this documentary evidence to blackmail her and curtail her liberty. To confirm the fearful powers of textual quotation, Crafts reveals Mr. Trappe's crime in a scene set in the library where, in a dramatic evocation of Jane Eyre, Hannah has been reading, in secret, behind a curtain. Surrounded by the monumental textuality of the past, Mr. Trappe repeats Mrs. Vincent's own prior agreement to support him financially in exchange for his silence, quoting her own words to justify his blackmail. In The Bondwoman's Narrative, the preserved and cleverly quoted text operates primarily as an instrument of domination and violence.

The tenacious grip of quotations does not cease once slaves flee in search of a new life in the North, for they are pursued not only by bounty hunters but also by documents-fugitive slave bills, advertisements, legal documents-that expose them and threaten their recapture. The quotation traditionally served as an instrument of education, social mobility, and authority, but Crafts demonstrates that liberty is a necessary precondition for the excerpt to effect this kind of change. For the slave, the quotation functions like a shackle, binding her to the recalcitrant legal past. Yet once Crafts herself moves north and adjusts to life in freedom, she can use quotations conventionally, as a medium for self-improvement. Quotations may enable mobility and education, but they do not override the ironclad statutes of the law.

Following the publication of these novels, the midcentury saw the proliferation of print collections that brought the authorizing power of the quotation to the general public. By this point, fewer readers were engaged in the practice of commonplacing, but excerpted quotations accrued new public prominence and ready accessibility, thanks to the rise of printed commonplace books that aggregated notable passages. Printed commonplace books were by no means new-Erasmus's print collection of select "Adages" was published in 1500-but now such books could be visible in numerous 
forms and under various titles. In these print settings, quotations came preselected by an editor, who excerpted previously published material and sometimes classified it under specific themes or topics. Sarah Hale, who in the 1830 s encouraged female readers to record commonplaces, issued a poetry commonplace book in 1849, A Complete Dictionary of Poetical Quotations, which included select quotations from both British and US poets. Doubtless the most famous midcentury commonplace book was John Bartlett's Familiar Quotations (1855), which sold out its first edition of a thousand copies within just three months and was issued in a second edition the following year (Regier 76). Dozens of such works were published at the time, such as Henry Southgate's Many Thoughts of Many Minds (1858), New Dictionary of Quotations (1859), and H. G. Adams's Cyclopedia of Poetical Quotations (1865) (Regier 79). Though for centuries commonplacing enabled social mobility only for those young men trained in the practice, printed commonplace books provided these maxims and proverbs, already chosen, for general use. The new availability of aphorisms did not cause their status to decline, but such quotations entered into common use as an authorizing rhetorical gesture, widely employed by Americans across the social spectrum. Indeed, quotation-filled novels of the midcentury functioned as a kind of printed commonplace book - albeit a more entertaining, engrossing kind - that similarly helped to transmit these excerpted quotations to countless readers who might not otherwise encounter them.

Ralph Waldo Emerson commented on the vogue for quotation in his 1859 essay "Quotation and Originality," in which he acknowledged the inevitability of such literary borrowings: "All minds quote. Old and new make the warp and woof of every moment. There is no thread that is not a twist of these two strands. By necessity, by proclivity and by delight, we all quote" (178). Emerson here acknowledges the powerful grip of quotations but concedes that the vestiges of the printed past may nonetheless contribute to the development of the new. In the case of the writers and texts examined here, quotation and imitation enabled the transformation of US authorial demographics, by credentialing women and people of color to enter the public world of print. At the same time, excerpted vestiges of the literary past also contributed to the rise of new literary forms, the epigraph and the quotation providing the necessary ballast for the controversial novel form.

Most important, the context of commonplacing also invites us to reconsider our field's esteem for originality and innovation as signature markers of literary importance. Novels by Brown, Crafts, and Sedgwick remind us that literary unoriginality had genuine value for much of the nineteenth century: the ability to follow convention and 
recite other people's words signaled respectability and ambition, with the well-chosen quotation helping to open doors for people otherwise excluded from the literary public. Furthermore, these texts also remind us that originality and innovation were prerogatives available chiefly to privileged white men, who could experiment without having to give ample assurances of their fidelity to tradition. As a result, quotation-filled novels of the nineteenth century attest to the significant struggles of white women and writers of color to find a place for themselves among a crowded literary market that required ample proof of their professional bona fides and declined to make room for the alternative voices and experiences of such writers as Crafts and Douglass. Their novels bear witness to their strenuous efforts to fit themselves into the literary tradition, as they offered the mandatory recitations of choice literary excerpts and wedged their own narratives, dialogue, and characters alongside these quotations by renowned writers. The advantages of quotation would ultimately prove short-lived, however: later generations of critics, such as T. S. Eliot and V. L. Parrington, would interpret these quotations as evidence of writers' lesser literary talent and inability to innovate, an assessment that justified their excision from the incipient literary canon. These later critics failed to recognize that, for these women and writers of color, deferential derivativeness was a deliberately chosen style that let them affirm their compliance with tradition and pass muster with literary gatekeepers. Our field's investment in originality has thus contributed directly to the exclusion of women and writers of color, and it is high time that we discard this longstanding disciplinary tenet. ${ }^{13}$

\section{Notes}

1. On this role, see Susan Miller, Assuming the Positions: Cultural Pedagogy and the Politics of Commonplace Writing (1998), p. 22; Ann Moss, Printed Commonplace-Books and the Structuring of Renaissance Thought (1996), p. vi; and Susan M. Stabile, Memory's Daughters: The Material Culture of Remembrance in Eighteenth-Century America (2004), p. 12.

2. On the economic metaphors for commonplacing, see Ann M. Blair, Too Much to Know: Managing Scholarly Information before the Modern Age (2010), p. 63.

3. Lydia Sigourney made this point explicit in The Girls Reading-Book (1837) with her statement that adults should continue the practice of notetaking learned in childhood (16). See also Carolyn Eastman, A Nation of Speechifiers: Making an American Public after the Revolution (2009), p. 21; E. Jennifer Monaghan, Learning to Read and Write in Colonial America (2005), p. 219; and Karen Sánchez-Eppler, "Copying and Conversion: An 1824 Friendship Album "from a Chinese Youth," American Quarterly, vol. 59, no. 2, June 2007, p. 301. 
4. See Michael C. Cohen, "Album Verse and the Poetics of Scribal Circulation," A History of Nineteenth-Century American Women's Poetry, edited by Jennifer Putzi and Alexandra Socarides (2016), pp. 68-86; Jillian Hess, “'This Living Hand': Commonplacing Keats," Keats-Shelley Review, vol. 24, no. 1, 2010, pp. 15-21; Hess, "Coleridge's Fly-Catchers: Adapting Commonplace-Book Form," Journal of the History of Ideas, vol. 73, no. 3, July 2012, pp. 463-83; Amanda Watson, "Shared Reading at a Distance: The Commonplace Books of the Stockton Family, 1812-40," Book History, vol. 18, 2015, pp. 103-33; and Laura Zebuhr, "The Work of Friendship in Nineteenth-Century American Friendship Album Verses," American Literature, vol. 87, no. 3, Sept. 2015, pp. 433-54.

5. This phenomenon is perhaps nowhere more evident than in Herman Melville's Moby-Dick (1851), which begins with a section appropriately titled "Extracts," a common synonym for commonplaces, which included dozens of extracted quotations about whales. Melville commenced his novel by grounding it in the familiar literary form of the commonplace book and displaying his own considerable research and knowledge of the subject.

6. Charlotte Havens Brooks, for instance, inscribed Radcliffe's poem "The Sea Mew." Charlotte Haven Brooks, MS Am 889.20, Houghton Library, Harvard University. Rebecca Story included a sonnet from Romance of the Forest. Rebecca Story Porter, commonplace book, MS Am 910, Houghton Library, Harvard University. Radcliffe's one surviving commonplace book is currently archived at the Boston Public Library. For an analysis of this volume, see Cheryl L. Nixon, "Ann Radcliffe's Commonplace Book: Assembling the Female Body and the Material Text," Women's Writing, vol. 22, no. 3, 2015, pp. 355-75.

7. Kari J. Winter has examined how the gothic enabled the discursive commingling of the antislavery and women's rights movements, though she does not examine how writers in these two movements respectively enlisted Ann Radcliffe's signature epigraphs. See Winter, Subjects of Slavery, Agents of Change: Women and Power in Gothic Novels and Slave Narratives, 1790-1865 (1992).

8. See, for instance, Meredith L. McGill, American Literature and the Culture of Reprinting, 1834-1853 (2003), pp. 141-86; Sidney P. Moss, Poe's Literary Battles: The Critic in the Context of His Literary Milieu (1963), pp. 132-89; and Edward J. Piacentino, "The Poe-Longfellow Plagiarism Controversy: A New Notice in The Southern Chronicle," Mississippi Quarterly, vol. 42, no. 2, Spring 1989, pp. 173-82.

9. Patricia Larson Kalayjian notes the novel's lackluster reception in 1830. See Kalayjian, "Disinterest as Moral Corrective in Clarence's Social Critique," Catharine Maria Sedgwick: Critical Perspectives, edited by Lucinda L. DamonBach and Victoria Clements (2003), p. 105.

10. Homestead and Foster translate the passage as follows: "The power to love is too great, and it is all too common in passionate souls" (Sedgwick 190).

11. See also Geoffrey Sanborn, “'People Will Pay to Hear the Drama': Plagiarism in Clotel," African American Review, vol. 45, no. 1-2, Spring-Summer 2012, pp. 65-82.

12. Hack also provides an extensive inventory of Crafts's reliance on Bleak House; see Hack, pp. 36-44. 
13. This claim echoes the foundational argument of Nina Baym's pioneering essay "Melodramas of Beset Manhood." In response to Baym's implicit call for interpretive methods attentive to the particulars of female authorship, my essay attempts to gloss the utility of unoriginality for many women writers and writers of color, a quality that, I contend, was often deliberate and purposeful. See Baym, "Melodramas of Beset Manhood: How Theories of American Fiction Exclude Women Authors," American Quarterly, vol. 33, no. 2, Summer 1981, pp. 123-39.

\section{Works Cited}

Allan, David. Commonplace Books and

Reading in Georgian England.

Cambridge UP, 2010.

Benedict, Barbara M. Making the Modern Reader: Cultural Mediation in

Early Modern Literary Anthologies.

Princeton UP, 1996.

Blair, Hugh. Lectures on Rhetoric and Belles Lettres. 1783. London: Baynes and Son, 1823.

Campbell, George. The Philosophy of Rhetoric. 1776. New York: Harper and Brothers, 1849.

Castle, Terry. Introduction. The Mysteries of Udolpho by Ann Radcliffe, edited by Bonamy Dobrée, Oxford UP, 2008, pp. vii-xxvi.

Crane, Mary Thomas. Framing Authority: Sayings, Self, and Society in Sixteenth-Century England. Princeton UP, 1993.

Crafts, Hannah. The Bondswoman's Narrative. Edited by Henry Louis Gates, Jr., Warner Books, 2002.

Day, Henry N. Elements of the Art of Rhetoric: A System of Rhetoric. 4th ed., New York: A.S. Barnes, 1866.

Douglass, Frederick. The Heroic Slave: A Cultural and Critical Edition. Edited by Robert S. Levine et al., Yale UP, 2015 .
Emerson, Ralph Waldo. "Quotation and Originality." 1859. Letters and Social Aims, AMS, 1968, pp. 175-204.

Fern, Fanny. Ruth Hall and Other Writings. Edited by Joyce W. Warren, Rutgers UP, 1986.

Genette, Gérard. Paratexts: Thresholds of Interpretation. 1987. Translated by Jane E. Lewin, Cambridge UP, 1997.

Grazia, Margreta de. "Sanctioning Voice: Quotation Marks, the Abolition of Torture, and the Fifth Amendment." The Construction of Authorship: Textual Appropriation in Law and Literature, edited by Martha Woodmansee and Peter Jaszi, Duke UP, 1994, pp. 281-302.

Hack, Daniel. Reaping Something New: African American Transformations of Victorian Literature. Princeton UP, 2017.

Havens, Earle. Commonplace Books: A History of Manuscripts and Printed Books from Antiquity to the Twentieth Century. Beinecke Rare Book and Manuscript Library, 2001.

Horrocks, Ingrid. “'Her Ideas Arranged Themselves': Re-membering Poetry in Radcliffe." Studies in Romanticism, vol. 47, no. 4, Winter 2008, pp. 507-27.

Kelley, Mary, editor. The Power of Her Sympathy: The Autobiography and 
Journal of Catharine Maria Sedgwick. Massachusetts Historical Massachusetts Historical Society, 1993. Society.

Keyser, Catherine. "Jane Eyre, Bondwoman: Hannah Crafts's Rethinking of Charlotte Brontë." In Search of Hannah Crafts: Critical Essays on The Bondwoman's Narrative, edited by Henry Louis Gates, Jr., and Hollis Robbins, Basic Civitas Books, 2004, pp. 87-105.

Levine, Robert S., et al. Introduction. The Heroic Slave by Frederick Douglass, Yale UP, 2015, pp. xi-xxxvi.

Logan, Shirley Wilson. Liberating Language: Sites of Rhetorical Education in Nineteenth-Century Black America. Southern Illinois UP, 2008.

Lynch, Deidre. "Gothic Libraries and National Subjects," Studies in Romanticism, vol. 40, no. 1, Spring 2001, pp. 29-48.

Miller, Susan. Assuming the Positions: Cultural Pedagogy and the Politics of Commonplace Writing. U of Pittsburgh P, 1998.

Morson, Gary Saul. The Words of Others: From Quotations to Culture. Yale UP, 2011.

Nord, David Paul. Faith in Reading: Religious Publishing and the Birth of Mass Media in America. Oxford UP, 2004.

Price, Leah. The Anthology and the Rise of the Novel: From Richardson to George Eliot. Cambridge UP, 2000.

Read, Lucinda. Journal and Commonplace-books. Ms. N-775.
Regier, Willis Goth. Quotology. U of Nebraska P, 2010.

Robbins, Hollis. "Blackening Bleak

House: Hannah Crafts's The

Bondwoman's Narrative." In Search of Hannah Crafts: Critical Essays on The Bondwoman's Narrative, edited by Henry Louis Gates, Jr., and Hollis Robbins, Basic Civitas Books, 2004, pp. 71-86.

Sanborn, Geoffrey. Plagiarama! William Wells Brown and the Aesthetic of Attraction. Columbia UP, 2016.

Sedgwick, Catharine Maria. Clarence; or, a Tale of Our Own Times. 1830. Edited by Melissa J. Homestead and Ellen A. Foster, Broadview Editions, 2012.

Sherman, William H. Used Books: Marking Readers in Renaissance England. U of Pennsylvania P, 2008.

Thornton, Tamara Plakins. Handwriting in America: A Cultural History. Yale UP, 1996.

Tuthill, Mrs. Louisa C. The Young Lady's Home. 1839. Philadelphia: Lindsay \& Blakiston, 1848.

Wilson, Kirt H. "The Racial Politics of Imitation in the Nineteenth Century." Quarterly Journal of Speech, vol. 89, no. 2, 2003, pp. 89-108.

Young, Edward. Conjectures on Original Composition. 1759. Scolar Press, 1966. 